\title{
Inflation Dynamics and Returns on Equity: The Nigerian Experience
}

\author{
Prince C. Nwakanma ${ }^{1} \&$ Arewa Ajibola ${ }^{2}$ \\ ${ }^{1}$ Department of Finance and Banking, University of Port Harcourt, Nigeria \\ ${ }^{2}$ Department of Banking and Finance, Lagos State University, Nigeria \\ Correspondence: Prince C. Nwakanma, Senior Lecturer and the immediate past Head of Department of Finance \\ and Banking at the University of Port Harcourt, Nigeria. E-mail: nwakanma5@yahoo.com
}

Received: October 27, 2010

Accepted: December 17, $2012 \quad$ Online Published: January 11, 2013

doi:10.5539/ijef.v5n2p164

URL: http://dx.doi.org/10.5539/ijef.v5n2p164

\begin{abstract}
Inflation in a developing economy is a dynamic force that shapes equity investment decisions. Equity being a variable income security has the potential of hedging inflation. This study examines inflation dynamism and equity returns using monthly data sourced from the various volumes of Central Bank of Nigeria (CBN) Statistical bulletin and Nigerian Stock Exchange (NSE) daily official list for a period of thirty- six months. The study utilizes the unrestricted vector autoregressive (UVAR) mechanism to examine the nature of the relationship between inflation and rate of return on equity. It was observed that inflation rises faster than rate of return on equity; and the nature of the relationship between inflation and return is found to be inconsistent over time. Furthermore, there are no causal effects between past inflationary rates and rate of return; though such effect is evident between current rates of inflation and immediate previous stock returns. Thus, the study recommends that Nigerian government should attempt to synchronise its monetary and fiscal policies in order to achieve stability in the economy. Also private sector productivity should be enhanced to reduce inflation and make returns on equity more attractive.
\end{abstract}

Keywords: inflation, return on equity, UVAR

\section{Introduction}

Conceptually inflation refers to the persistent rise in prices of goods and services over a period of time. A moderate presence of inflation in the economy is considered a necessary condition because of its positive effect on economic activities. However a high rate of inflation can be detrimental to investment. The import of this is that the return on investment (i.e. equity, bond or real estate) can be significantly influenced by inflation. The notion about the relationship between inflation and return on asset/equity was first developed and celebrated by (Fisher, 1930). This was called the Fisher effect which explained the relationship between asset returns and inflation. For a period of forty years, starting from 1930 to 1970, this effect remained as the logical explanation for equity-inflation relationship, as it reinforced the doctrine that an asset's underlying value can be maintained in the presence of inflation. Ely and Robinson (1997) used the data extracted from 16 industrialized economies to test the nature of the relationship between stock return and inflation, and found that stock market prices maintain their value in the face of inflation. Similarly, Luinted and Paudyal (2006) based their analysis of inflation-return relationship on the different sectors within the UK stock market and established an evidence to support the Fisher economic hypothesis, which is referred to as the "Fisher effect".

However, many studies seem to cast doubts on the empirical standing of Fisher's hypothesis as conflicting results trail the return-inflation relationship. These apparent inconsistencies in findings are well documented (Nelson, 1975; Jaffee and Mandelker 1976; Bodie 1968; Fama and Schwert, 1977; Modigliani and Cohn, 1979). The implication of these findings is that stock returns and inflation are inversely related. More recent studies tend to support the evidence of negative relationship between stock return and inflation, Sharpe (2002), Campbell and Vuolteenaln (2004), Chordia and Shivakumar (2005) and Basu et al (2005). This extant relationship is commonly referred to as the "Fed Model" of stock pricing (Estrada, 2009). In this respect, Estrada (2009) suggests that this negative relationship between the stock market price-earnings ratio and government bond yields is now seen by practitioners as conventional. Practitioners have argued that bond yields plus risk premium equate to nominal yield on stocks and that actual stock yield tends to revert to this nominal yield, 
Campbell and Vuolteenaln (2004). It is proposed by Asness (2003) that the model erroneously compares the real magnitude of the earnings-price ratio to nominal government bond yields.

Given the divergent opinions regarding the Fisher effect and Fed model, the aim of this study is to shade more light on the relationship between inflation dynamics and stock returns in Nigeria, as an example of a developing economy. Having introduced the study, the rest of the paper takes the ensuing structure: section two is a review of literature. Section three dwells on methodology and data; while empirical results, conclusion and recommendation are respectively presented in sections four, five and six.

\section{Literature Review}

Traditionally, it was believed that stocks provide a good hedge against inflation because as variable income securities their returns should compensate for any changes in inflation. In recent years, empirical research shows that inflation affects stock returns negatively (Sharpe 1999). In the United States, high expected inflation and accelerating inflation have been associated with decreasing price/earnings ratios. Stocks seem to be better hedges against inflation in the medium-term and long- term compared to the short-run.

However, Fisher (1930) argues that return on assets move one - for - one with anticipated inflation. That is, stocks should be inflation neutral but stock prices react negatively to high unexpected inflation. Fisher reasons that real stock retunes are related to real factors and those stocks should maintain their purchasing power in the long-term. Fama and Schwert (1977) argue that anticipated inflation negatively affects stock returns during the period 1953-1971 and conclude that stocks are not good hedges against inflation. Cohn and Modigliani (1979) argue that U.S investors undervalue stocks because they discount (mistakenly) future real cash flows by using nominal rates of return. They use quarterly data over 1953-1977 on price /earnings ratios and inflation rates in their analysis.

Lansing (2004) confirms the behavioral anomaly of investors discounting future real cash flows by nominal rates of return. It is well established in the literature that rising inflation and future real economic growth are negatively correlated. During the 1970s, the U.S. experienced a decline in economic activity when inflation was rising, (Hoguet, 2009). This view is confirmed by Fama (1981), who argues that stock returns are positively related to the expected real rate of economic growth. Future real economic growth is on the other hand, associated with low inflation rates. When future economic growth (in real terms) is expected to decline due to high inflation, investors required higher risk premiums on their stocks.

The negative short-term relationship between stock returns and anticipated and unanticipated inflation is reported by Geske and Roll (1983) and Jaffe and Mandelker (1976) and Wei (2009). Wei observes that the negative reaction of stock returns to unanticipated inflation is higher during economic contractions than expansions. On the other hand, the long - run positive relationship (Fisher effect) is reported by many authors. Jaffe and Mandelker report positive relationship over a long period (1875 -1970). Boudoukh and Richardson (1993) confirm the same result applying one-year and five- year holding period returns during 1802-1990 in both the United Kingdom and the United States.

Anari and Kolari (2001) use stock prices and goods prices instead of the first difference in order to overcome the problem that the first difference eliminates the long - run information. They use monthly stock price indices and goods price indices for Canada, France, Germany, the United Kingdom and the United states during 1953-1998. They employ the co-integration technique developed by Johansen (1988) for the goods prices and stock prices which they discover are co-integrated and stationary at level data, confirming the long memory Fisher effect which says that stocks are good inflation hedges over a long holding period. However, they also report the negative initial effect in all six countries. Luintel and Paudyal (2006) support previous results and report the existence of the long - run hedging relationship in the UK stock market.

Although the short-run negative effect (the inflation illusion as named by Modigliani and Chon (1979)) and the long - run hedging Fisher effect are well established in empirical research, Ely and Robinson (1997) do not find any long - run relationship. They apply the Johansen's (1988) method on sixteen countries during 1957-1992. Aga and Kocaman (2006) tested the impact of price/earnings ratios, industrial price indices (IPI) and the consumer price indices (CPI) on returns of stocks traded in Istanbul stock Exchange. They claim that macroeconomic variables such as inflation rates should have two possible effects. The direct effect hypothesis implies that stock markets normally react negatively to bad news and positively to good news. The policy signaling hypothesis implies that it is possible for the market to react positively to adverse movements in macroeconomic variables due to anticipated government remedial actions. 
Their findings indicate that only the price/earnings ratio appears to be significant in explaining the movements in stock returns, while industrial price indices and consumer price indices are not. Exponential GARCH model was applied to test the impact of CPI and IPI on stock return and volatility. They also found that these variables are not statistically significant in explaining stock returns and volatility.

\section{Methodology and Data}

This study adopts an unrestricted vector autoregression (UVAR) frame work which was pioneered by Sims (1980) as a dynamic model that shows time series relationship among macroeconomic variables. Thus, in this study UVAR technique is used to analyse the dynamic relationship between inflation and stock returns. The stochastic form of the model is stated below:

$$
\mathrm{In}=\lambda_{0}+\lambda_{1} \sum_{\mathrm{t}=0}^{\mathrm{n}} \quad \operatorname{In}_{(1-\mathrm{t})}+\lambda_{2} \quad \sum_{\mathrm{t}=0}^{\mathrm{n}} \quad \prod_{(1-\mathrm{t})}+\varepsilon_{\mathrm{t}} ; \mathrm{t}=1,2, \ldots \ldots \ldots \mathrm{n}
$$

Where: In presents rate of inflation

$\prod$ represents return on equity

$\sum$ represents summation

$\lambda_{0,}, \quad \lambda_{1}$ and $\lambda_{2}$ are the regression parameters

And $\varepsilon_{\mathrm{t}}$ is the error term.

This study covers the Nigerian equity market and uses monthly consumer price index (CPI) and monthly stock returns which are respectively obtained from CBN Statistical bulletin and Monthly stock Review of Nigerian Stock Exchange (NSE). The sample period begins in January 2007 and ends in December 2009 with a total number of observations of 36. Based on the literature on this subject, Aga and Kocaman (2006); we infer that our sample size is relatively large to provide robust and reliable results on our UVAR test.

\section{Estimation and Empirical Results}

In order to gain deeper insight into the dynamic relationship between inflation and stock returns in Nigeria, the study adopts a two-stage analysis comprising of descriptive statistics and inferential statistics. The essence of the descriptive view of the nature of inflation and stock returns is to have an impression of the general behaviour of the variables. The descriptive statistics for the study include mean, minimum, maximum, skewness, kurtosis and Jarque-Bera. The outputs results obtained in respect of these statistics are reported in Table 1 below.

Table 1. The results of selected descriptive statistics

\begin{tabular}{llllllll}
\hline Statistic & In & $\operatorname{In}(-1)$ & $\operatorname{In}(-2)$ & $\operatorname{In}(-3)$ & $\Pi(-1)$ & $\prod(-2)$ & $\Pi(-3)$ \\
\hline Mean & 73.31 & 65.52 & 58.06 & 50.87 & 0.24 & 0.27 & 0.24 \\
Minimum & 2.36 & 2.15 & 1.89 & 1.87 & -0.46 & -0.16 & -0.16 \\
Maximum & 181.3 & 173.50 & 167.40 & 157.10 & 0.58 & 0.58 & 0.51 \\
Skewness & 0.44 & 0.54 & 0.64 & 0.72 & -0.99 & -0.54 & -0.46 \\
Kurtosis & 1.83 & 1.98 & 2.16 & 2.31 & 3.49 & 2.28 & 2.02 \\
Jarque-Bera & 2.04 & 2.13 & 2.28 & 2.28 & 4.00 & 1.61 & 1.74 \\
Probability & 0.36 & 0.34 & 0.32 & 0.32 & 0.14 & 0.45 & 0.42 \\
Observation & 23 & 23 & 23 & 23 & 23 & 23 & 23 \\
\hline
\end{tabular}

Source: Computed from E-View Programm

Table 1 shows the values of skewness, kurtosis and Jarque -Bera statistics for inflation and return on equity at levels and at different lag structures. The values are not found to be significant as revealed by their probabilities which are obviously larger than five percent (5\%). This means that overtime the rates of inflation and returns on equity are not normally distributed in Nigeria. The minimum and maximum values in Table 1 shows that inflation rates and returns on equity have been increasing persistently over time in Nigeria; the average values of returns on equity under the period of analysis are found to be very low: while the average value of inflationary rates appears to be high for an emerging economy like Nigeria to sustain growth (see these values in Table 1). It can be seen from these results that inflation increases at faster rate than return on equity, which is an indication that equity investors in Nigeria are not getting adequate protection from the ravages of inflation in the economy.

The next phase of the study is to determine the relationship between inflation and return on equity. Since the study uses time series data it is important to test for stationarity to avoid the use of non-stationary data and the 
spurious results that will arise. In doing this, Im Pesaran and Shin W-stat, Augumented Dickey Fuller (ADF)-Fisher Chi-Square and Philip Paron-Fisher Chi-square Tests are conducted. As can be seen from Table 2, the probability values at levels $\mathrm{I}(0)$ are $0.49,0.04 \& 0.05$ for $\mathrm{Im}$ Pesaran and Shin W-Stat, ADF-Fisher-Chi-Square and PP-Fisher-Chi-Square respectively. Also, the probability values at first difference I(1) for these three tests are $0.07,0.06 \& 0.07$ respectively. In all cases the probability values are larger than one percent $(1 \%)$. This indicates that the Null hypothesis that there is no unit root is not rejected. But however, considering the 5\% level of significance, the series are stationary at levels and at first difference, except in the case of Im Pesaran and Shin W-Statistical Test. Based on this test the series of the specified variables fail the condition of testing for cointegration. We therefore utilize the Unrestricted Vector Autoregressive (UVAR) mechanism for analyzing the nature and magnitude of the relationship between inflationary rates and returns on equity at different lags.

Table 2. The unit root test results

\begin{tabular}{lllll}
\hline Test Type & Lag(-1) Stat Value & P.V & Lag (0) Stat Value & P.V \\
\hline Im Perasan and Shin W-Stat & -1.49 & 0.07 & -0.03 & 0.49 \\
ADF-F isher Chi-Square & 9.02 & 0.06 & 9.79 & 0.04 \\
PP-Fisher Chi-Square & 8.68 & 0.07 & 9.54 & 0.05 \\
\hline
\end{tabular}

Note: PV means probability value

Source: Computed from E-view Programm

The nature of the relationship between inflation and equity return is an important determinant of economic growth. Thus, the analysis and estimation of this relationship is carried using UVAR mechanism. The results obtained are presented in Table 3

Table 3. Unrestricted vector autoregressive results

\begin{tabular}{llllll}
\hline Variables & $\operatorname{In}(-1)$ & $\operatorname{In}(-2)$ & $\Pi(0)$ & $\Pi(-1)$ & $\Pi(-2)$ \\
\hline coefficient & 1.55 & -0.52 & 9.23 & -3.61 & 4.98 \\
& $(0.21)$ & $(0.22)$ & $(3.95)$ & $(4.30)$ & $(4.46)$ \\
& {$[7.55]^{*}$} & {$[-2.34]^{*}$} & {$[2.34]^{*}$} & {$[-0.84]$} & {$[1.12]$} \\
\hline
\end{tabular}

R-square $=0.99, \mathrm{~F}$-Statistic $=912.98$; Note- the figures in parenthesis are the standard error and $\mathrm{t}$-values, $*$ denotes significant at $5 \%$.

Table 3 reports the results of the estimated UVAR equation at five percent level of significance using one tale test. The coefficients of inflationary rate at lag one is 1.55 and at lag two is -0.52 and their corresponding $\mathrm{t}$-values are 7.55 and -2.34 respectively. In comparism, $\mathrm{t}$-values are larger than the critical $\mathrm{t}$-value 2.10 at $5 \%$. This implies that previous rate of inflation are significantly related, reveal that the nature of the relationship between the present and past inflationary rates are inconsistent over time; since the coefficient of the lag rate is positive while that of the lag two is negative. This could be as a result of policy implementation to tame inflation. Thus, in Nigeria, present and past inflationary rates are both positively and negatively related. In the same token, current return on equity has a coefficient of 9.23 with observed t-value of 2.34 at $5 \%$ level of significant. This equally suggests to us that moderate level of inflation is significant to boost stock returns in Nigeria. However, the previous stock returns are found to be inconsistent in their nature of relationships with inflationary rates. This instability is probably due to faulty and mal-adjusted monetary/fiscal policy.

It is plausible to determine the direction of between inflation rate and return on causality between inflation rate and return on equity. In view of this, the study employs Granger Causality test to investigate whether inflation Granger causes return or vice-versa. The results obtained from this test are presented in Table 4 
Table 4. Granger causality test results

\begin{tabular}{|c|c|c|c|}
\hline Null Hypothesis & Obv & F-Statistic & P.V \\
\hline$\prod$ does not Granger cause In & 24 & 0.30 & 0.74 \\
\hline In does not Granger cause $\prod$ & & 1.32 & 0.29 \\
\hline П(-1) does not Granger cause In & 23 & 0.09 & 0.91 \\
\hline In does not Granger cause $\prod(-1)$ & & 5.28 & 0.02 \\
\hline$\prod(-2)$ does not Granger cause In & 22 & 0.28 & 0.76 \\
\hline In does not Granger cause $\prod(-2)$ & & 0.03 & 0.97 \\
\hline$\prod$ does not Granger cause In & 23 & 2.50 & 0.11 \\
\hline In (-1) does not Granger cause $\prod$ & & 1.39 & 0.28 \\
\hline$\prod(-1)$ does not Granger cause In(-1) & 23 & 0.72 & 0.50 \\
\hline In (-1) does not Granger cause $\prod(-1)$ & & 1.43 & 0.27 \\
\hline$\prod(-2)$ does not Granger cause In (-1) & 22 & 0.18 & 0.83 \\
\hline In $(-1)$ does not Granger cause $\prod(-2)$ & & 1.24 & 0.31 \\
\hline$\prod$ does not Granger cause $\operatorname{In}(-2)$ & 22 & 1.20 & 0.32 \\
\hline In(-2) does not Granger cause $\prod$ & & 2.09 & 0.15 \\
\hline$\prod(-1)$ does not Granger cause In (-2) & 22 & 1.49 & 0.25 \\
\hline In (-2) does not Granger cause $\prod(-1)$ & & 1.69 & 0.25 \\
\hline$\prod(-2)$ does not Granger cause In (-2) & 22 & 0.78 & 0.48 \\
\hline In (-2) does not Granger cause $\prod(-2)$ & & 0.68 & 0.52 \\
\hline
\end{tabular}

Source: Computed from E-View Programm

A quick view of the Granger Causality Test results on Table 4 shows that the observed F-Statistics are smaller than the critical F-value (2.74) at 5\% level of significance in all the rows except in row two where the observed F-value is found to be 5.28. The results depicted in the second row imply that there is unidirectional causality effect between current inflation and return on equity at lag one with the direction of flow tricking down from the rate of inflation. Conversely, the results obtained in all other rows indicate that there is no causality between lagged inflation and return. It simply means that previous inflationary rates do not Granger cause previous/ past returns on equity. Thus, maintain zero causality.

\section{Summary and Conclusion}

The study examines the relationship between inflationary rates and returns on equity using the UVAR mechanism. The results obtained provide an evidence to support the assertion that there is inconsistency in the nature of the relationship between inflation and returns on Equity in Nigeria. Our findings further shows that the rates of inflation and returns on equity have been increasing over time; but inflation rates rise faster than the returns on equity. In fact, the margin is found to be significant and detrimental to economic growth in Nigeria. Finally, we discover that there is no causal effect between previous inflationary rates and previous returns. This means that past rates of inflation do not Granger cause past return. However, a unidirectional effect is evident between current inflation and return at lag one with the direction of flow trickling down from inflation. Thus, current inflation Granger cause immediate past return on equity in Nigeria.

\section{Recommendations}

The study recommends that Nigerian government should attempt to synchronise the nation's existing monetary and fiscal policies so as to achieve greater economic stability. The Nigerian private sector should enhance productivity in order to rein in on inflation and generate real growth in return on equity. If the divergence between inflation and return on equity can be narrowed down it will stimulate economic growth and development. It will also create greater impetus for capital market activities in Nigeria.

\section{References}

Aga, M., \& Kocaman, B. (2006). An Empirical Investigation of the Relationship Between Inflation, P/E Ratios and Stock Price Behaviours Using a New series called Index-20 for Istanbul Stock Exchange. International Research Journal of Finance and Economics, 6.

Anari, A., \& Kolari, J. (2001). Stock Prices and Inflation. The Journal of Financial Research, XXIV(4),, 587-602.

Asness, C. (2003). Fight the Fed model. Journal of portfolio Management, 11-24. http://dx.doi.org/10.3905/jpm.2003.319916 
Basu, S., Markov, S., \& Shivakumar, L. (2005). Do Financial Analysts suffer from Inflation Illusion? Working Paper, Emory University

Bodie, Zvi. (1976). Common stocks as a hedge against inflation. Journal of Finance, 31, 451-470. http://dx.doi.org/10.1111/j.1540-6261.1976.tb01899.x

Boudoukh, J., \& M. Richardson. (1993). Stock returns and inflation: A long-horizon Perspective. American Economic Review, 83, 1346-1355.

Campbell, J. Y., \& Vuolteenaho, T. (2004). Inflation illusion and stock prices. American Economic Review, 19-23. http://dx.doi.org/10.1257/0002828041301533

Chordia, T., \& Shivakumar, L. (2005). Inflation Illusion and Post-Earnings-Announcement Drift. Journal of Accounting Research, 23(4), 521-556. http://dx.doi.org/10.1111/j.1475-679X.2005.00181.x

Ely, D., \& Robinson, K. J. (1997). Are stocks a hedge against inflation? International evidence using a long run approach. Journal of International Money \& Finance, 16(1), 141-167. http://dx.doi.org/10.1016/S0261-5606(96)00039-3

Ely, P. D., \& Robinson, K. J. (1997). Are Stocks a Hedge against inflation? International Evidence using a Long -run Approach. Journal of International Money and Finance, 16, 141-67. http://dx.doi.org/10.1016/S0261-5606(96)00039-3

Estrada, J. (2009). The Fed Model: The bad, the worse and the ugly. The Quarterly Review of Economics and Finance, 49, 214-238. http://dx.doi.org/10.1016/j.qref.2007.03.007

Fama, E. F. (1981). Stock returns, real activity, inflation and money. American Economic Review, 71, 545-565.

Fama, E. F., \& W. G. Schwert. (1977). Asset returns and inflation. Journal of Financial Economics, 5, 115-146. http://dx.doi.org/10.1016/0304-405X(77)90014-9

Fisher, I. (1930). The Theory of Interest, (Macmillan, New York) Jaffe, J. and Mandelker, G., 1976, The Fisher Effect for Risky Assets: an Empirical Investigation. Journal of Finance, 31, 447-58.

Fisher, R. A. (1930). The General Theory of Natural Selection. Oxford University Press, Oxford

Geske, R., \& R. Roll. (1983). The fiscal and monetary linkage between stock returns and Inflation. Journal of Finance, 38, 1-33.

Hoguet, G. R. (2009). Inflation and Stock Prices, State Street Global Advisors. Geske R. and Roll, R., 1983, The Fiscal and Monetary Linkages between Stock Returns and Inflation. Journal of Finance, 38, 1-33

Jaffe, J., \& Mandelker, G. (1976). The Fisher effect for risky assets: An empirical investigation. Journal of Finance, 31, 447-458. http://dx.doi.org/10.2307/2326616

Johansen, S. (1988). Statistical Analysis of Cointegration Vectors. Journal of Economic Dynamics and Control, 12, 231--254. http://dx.doi.org/10.1016/0165-1889(88)90041-3

Lansing, K. J. (2004). Inflation- induced Valuation Errors in the Stock Market. FRBSF Economic letter, number 2004-30.

Luintel, K., \& Paudyal, K. (2006). Are Common Stocks a Hedge against Inflation?. Journal of Financial Research, 29, 1-19. http://dx.doi.org/10.1111/j.1475-6803.2006.00163.x

Modigliani, F., \& Cohn, R. A. (1979). inflation, Rational valuation and the Market., Financial Analysts Journal, 35, 28. http://dx.doi.org/10.2469/faj.v35.n2.24

Nelson, C. (1976). Inflation and rates of return on common stocks. Journal of Finance, 31, 471-483. http://dx.doi.org/10.1111/j.1540-6261.1976.tb01900.x

Phillips, P., \& Perron, P. (1990) Testing for a unit root in time series regression. Biometrika, 75, 335-346. http://dx.doi.org/10.1093/biomet/75.2.335

Sharpe, S. A. (2002). Re-examining stock valuation and inflation: The implications of analysts' earnings forecasts. The Review of Economics and Statistics, 84(4), 632-648. http://dx.doi.org/10.1162/003465302760556468

Sims, C. A. (1980). Comparison of interwar and postwar business cycles: Monetarism reconsidered. American Economic Review, 70, 250-257. 